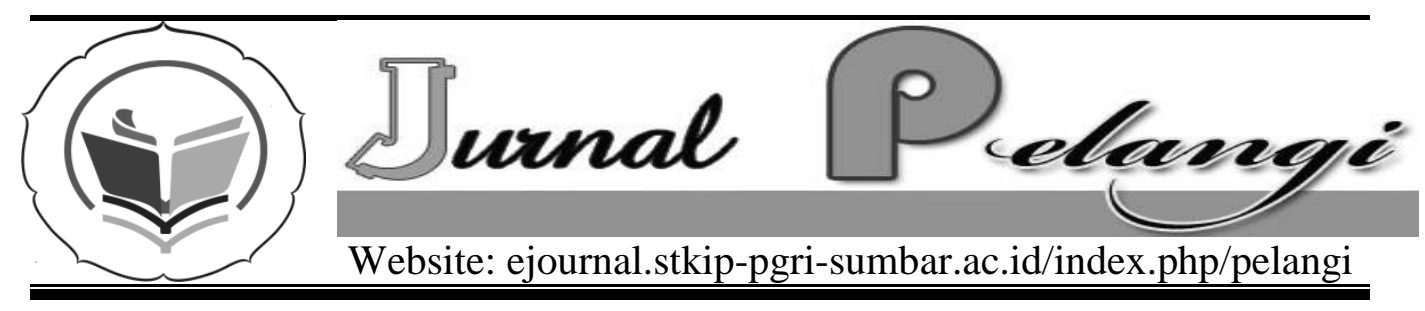

\title{
PENGARUH DANA ALOKASI UMUM (DAU) DAN PENDAPATAN ASLI DAERAH (PAD) TERHADAP BELANJA DAERAH PADA KABUPATEN/KOTA DI PROVINSI SUMATERA BARAT
}

\author{
Jolianis
}

STKIP PGRI Sumatera Barat

joulianiskoto@ymail.com

\begin{tabular}{ll}
\hline \multicolumn{2}{l}{ INFO ARTIKEL } \\
\hline $\begin{array}{l}\text { Diterima } \\
\text { Disetujui }\end{array}$ & $: 01-01-12-2014$ \\
\end{tabular}

Kata Kunci:

Dana AlokasiUmum

(Dau),

PendapatanAsli

Daerah (Pad),

Belanja Daerah

Keywords:

\section{General}

Allocation Fund,

local revenue

againstExpenditure

\section{Abstrak}

Penelitian ini adalah untuk membuktikan secara empiris : 1) Pengaruh dan aalokasi umum terhadap belanja daerah. 2) Pengaruh pendapatan asli daerah terhadap belanja daerah. Penelitian ini menemukan bahwa : 1) Dana Alokasi Umum berpengaruh signifikan terhadap belanja daerah. Peningkatan jumlah Dana alokasi Umum akan mengakibatkan peningkatan pada jumlah Belanja Daerah yang akan dikeluarkan oleh pemerintah daerah. 2) Pendapatan Asli Daerah berpengaruh signifikan terhadap belanja daerah. Peningkatan jumlah Pendapatan Asli Daerah akan mengakibatkan peningkatan pada jumlah Belanja Daerah yang akan dikeluarkan oleh pemerintah daerah.

\section{Abstract}

This studyis to demonstrate empirically: 1) The effect ofthe General Allocation Fundto Expenditure. 2) The effect oflocal revenue against Expenditure. This studyfound that: 1) General Allocation Funda significant effect onlocalspending. Increasingthe amount of General Fundallocation will result inan increasein the number of Expenditureto be incurredby the local government. 2) the original incomesignificantly influence the shopping area. Increasingthe amount ofthe original incomewillresult inan increasein the number of Expenditureto be incurredby the local government

\section{PENDAHULUAN}

Respontiap-tiap daerah di Provinsi Sumatera Barat terhadap dana transfer yang diberikan oleh pemerintah pusat berbeda-beda. Tidak semua daerah Kabupaten/Kota di Provinsi Sumatera Barat memiliki kesiapan 
dalam menerima dana transfer tersebut. Dampaknya adalah terjadi perilaku yang tidak simetris sebagai respon terhadap dana transfer yang diberikan. Ketika pemerintah pusat memberikan bantuan transfer kepada pemerintah daerah sebagai upaya untuk meningkatkan belanja daerah, terdapat indikasi respon yang asimetris terhadap bantuan tersebut. Transfer pemerintah pusat tentunya berpengaruh terhadap besarnya pengeluaran yang dilakukan oleh pemerintah daerah kabupaten atau kota. Pada saat pemerintah daerah Provinsi Sumatera Barat menerima transfer dari pemerintah pusat dana itu digunakan tanpa adanya upaya untuk meningkatkan PAD tiap-tiap daerah.

Peningkatan alokasi transfer diikuti dengan pertumbuhan belanja yang lebih tinggi. Hal ini dapat menunjukkan adanya indikasi bahwa peningkatan belanja yang tinggi tersebut dikarenakan inefisiensi belanja pemerintah, terutama belanja operasional. Selain itu pada saat transfer dana dari pemerintah pusat menurunmaka juga diikuti oleh penurunan belanja daerah yang melebihi penurunan PAD. Kecenderungan ini menunjukkan ketergantungan pemerintah daerah kepada pemerintah pusat masih tinggi, sehingga dalam jangka panjang ketergantungan ini seharusnya dikurangi, karena akan berdampak negative pada kemandirian daerah. Saat masyarakat (pemerintah daerah) menerima transfer maka akan terjadi kenaikan penerimaan pajak daerah dan peningkatan konsumsi barang publik. Hal ini menunjukkan bahwa transfer meningkatkan konsumsi akan barang public namun tidak menjadi substitute pajak daerah.

Pendapatan Asli Daerah (PAD) Provinsi yang ada di Sumatera Bagian Selatan mengalami peningkatan setiap tahunnya, tetapi Dana Alokasi Umum yang diterima dari pemerintah pusat juga mengalami peningkatan yang cukup tinggi setiap tahunnya. Hal ini tentunya mengindikasikan bahwa masih tingginya tingkat ketergantungan Provinsi yang ada di Sumatera Bagian Selatan terhadap transfer pemerintah pusat. Selanjutnya juga terlihat belanja daerah setiap tahunnya jauh lebih besar dibandingkan dengan Pendapatan Asli Daerah (PAD), tentunya hal ini juga memperkuat alasan bahwa Provinsi yang ada di Sumatera Bagian Selatan sangatmengharapkan transfer dari pemerintah pusat untuk menutupi belanja daerah setiap tahunnya. Dengan demikian dapat dikatakan bahwa sumber pembiayaan daerah in masih mengharapkan transfer dari pemerintah pusat, karena objek pajak danr etribusi daerah yang ada sangat terbatas sebagai sumber pendapatan daerah.

Permasalahan yang terjadi saat ini adalah pemerintah daerah terlalu 
menggantungkan alokasi DAU untuk membiayai belanja modal dan pembangunan tanpa mengoptimalkan potensi yang dimiliki daerah. Di saatalokasi DAU yang diperoleh besar, maka Pemerintah Daerah akan berusaha agar pada periode berikutnya DAU yang diperoleh tetap. Proporsi DAU yang digunakan untuk menutupi belanja daerah pada Provinsi Sumatera Barat relative tinggi dibandingkan dengan penggunaan PAD. Artinya, pemerintah daerah lebih mengandalkan dana alokasi umum untuk keperluan belanja daerah sehingga hal ini mengindikasikan terjadinya flypaper effect pada keuangan daerah pada Kabupaten/Kota di Provinsi Sumatera Barat. Dalam menghadapi permasalahan ini tentunya diperlukan upaya khusus untuk mengatasi agar pemerintah daerah tidak selalu bergantung kepada dana alokasi umum untuk menutupi belanja daerah.

Rumusan masalah pada penelitian ini adalah:

1. Apakah Dana AlokasiUmum (DAU)

berpengaruhterhadapBelanja

Daerah (BD)?

2. ApakahPendapatanAsli Daerah (PAD)

berpengaruhterhadapBelanja

Daerah (BD)?

\section{METODE PENELITIAN}

1. Model TahapanPenelitian a. Mengumpulkan data Penelitian ini menggunakan data sekunder maka langkah pertama peneliti akan mengumpulkan data berbentuk data pool times series berupa selama 5 tahun terakhir yaitu tahun 2008 2012.

b. Mengolah data

c. Menganalisis data

\section{Lokasi Penelitian}

Penelitian ini dilakukan pada Pemerintah Kabupaten/Kota di Provinsi Sumatera Barat yang berjumlah 19 Kabupaten/Kota. Waktu penelitian direncanakan pada tahun 2014.

\section{Peubah yang diamati/diukur}

a. Variabel Terikat (Dependent Variabel). Belanja Daerah secara keseluruhan (Y) yang disingkat dengan BD merupakan semua pengeluaran dari rekeningka sumum daerah yang mengurang iekuitas dana, merupakan kewajiban daerah dalam satu tahun anggaran dan tidak akan diperoleh pembayaran kembali oleh daerah dalam satu periode.

b. Variabel

Bebas (Independent Variabel)

1) Dana Alokasi Umum (X1) yang disingkat 
dengan DAU merupakan dana yang berasal dari APBN, yang dialokasikan dengan tujuan pemerataan kemampuan keuangan antar daerah untuk membiayai kebutuhan pembelanjaan dalam rangka pelaksanaan desentralisasi.

2) Pendapatan Asli Daerah (X2) yang disingkat dengan PAD merupakan Pendapatan Asli Daerah adalah total pendapatan daerah Kabupaten/Kota di Provinsi Sumatera Barat yang berasal Pajak Daerah, Retribusi Daerah, Pendapatan dari Laba Perusahaan Daerah dan lain-lain pendapatan. Data pendapatan asli daerah pada penelitian diukur dalam satuan rupiah

4. Model yang digunakan

$\mathrm{Y}=\mathrm{a}+\mathrm{b} 1$ DAU1 $\mathrm{i}+\mathrm{b} 2$ PAD2 $\mathrm{i}$

$+\mathrm{e}$

Keterangan :

$\mathrm{Y}=$ Belanja Daerah (BD)

a $=$ Konstanta

b1 b2 = KoefisienRegresi

DAU = Jumlah DAU

PAD = Jumlah PAD

$\mathrm{e}=$ error term

\section{TeknikAnalisis Data}

a. PengujianAsumsiKlasik

1) UjiNormalitas
Uji normalitas dilakukan dengan maksud memeriksa apakah data yang berasal dari populasi yang terdistribusi normal atau tidak. Menurut Santoso (2002) pedoman yang dipakai dalam uji normalitas ini adalah mengunakan uji Kolmogorov Smirnov yaitu :

1. Jika nilai signifikansi lebih besar dari alpha $(\alpha=0,05)$ maka distribusi data adalah normal

2. Jika nilai signifikansi lebih kecil dari alpha $(\alpha=0,05)$ maka distribusi data adalah tidak normal.

\section{2) UjiMultikolinieritas}

Pada penelitian ini uji multikolinearitas dilakukan dengan bantuan software SPSS. Menurut Gujarati (2003) untuk mengetahui ada atau tidaknya masalah multikolineritas dapat dilihat dari nilai VIF (Variance Inflation Factor) dilakukan dengan rumus :VIF= $\frac{1}{\left(1-r^{2} \beta i j\right)}$

Dengan kriteria sebagai berikut:

a) Jika nilai VIF > 10, berarti terdapat korelasi yang tinggi sesama variabel bebas, maka terdapat multikolineritas pada tingkat kepercayaan $95 \%$

b) Jika nilai VIF $<10$, berarti tidak terdapat multikolineritas pada tingkat kepercayaan $95 \%$.

\section{3) UjiAutokorelasi}


Dalam studi ini akan digunakan uji Durbin Watson (DW) karena nilai statistik DW biasanya selalu muncul dalam setiap hasil regresi menggunakan Eviews. Adapun kaidah atau ketentuan penerimaan Durbin Watson adalah sebagai berikut (Gujarati, 2003);

- $\mathrm{DW}<\mathrm{dl}=$ terdapat autokorelasi positif

- $\mathrm{dl}<\mathrm{DW}<\mathrm{du}=$ daerah keraguraguan/tidak dapat disimpulkan

- $\quad \mathrm{du}<\mathrm{DW}<4$-du DW = Tidak ada autokorelasi

Homokedastisitas. Sedangkan jika varians berbeda, maka disebut heterokedastisitas.Sedangkan model regresi yang baik adalah jika tidak terjadinya heterokedastisitas.Untuk mendeteksi adanya heterokedastisitas dapat menggunakan uji Gletser. Dalam uji ini apabila hasilnya Sig > 0,05 maka tidak terdapat gejala heterokedastisitas, model yang baik adalah tidak terjadi heterokedastisitas. (Ghozali, 2005).

\section{b. Pengujian Hipotesis}

Penelitian ini menggunakan alat analisis yaitu regresi linear berganda (multiple regression). Analisis regresi linear berganda digunakan untuk penguji pengaruh beberapa variabel bebas terhadap variabel terikat. Adapun persamaan
- 4-du $<\mathrm{DW}<4-\mathrm{dl}=$ daerah keragu-raguan/tidak dapat disimpulkan

- $\mathrm{DW}>4$-dl = terdapat autokorelasi negatif

\section{4) Uji Heteroskedastisitas}

Uji Heterokedastisitas bertujuan untuk menguji apakah dalam sebuah model regresi terjadi ketidaksamaan varian dari residual suatu persamaan ke pengamatan lain. Jika varians dari residual dari satu pengamatan ke pengamatan lain tetap, maka disebut dari hipotesis 3 adalah sebagai berikut :

$$
\begin{aligned}
& \mathrm{Y}=\mathrm{a}+\mathrm{b} 1 \text { DAU1i }+\mathrm{b} 2 \text { PAD2i }+\mathrm{e} \\
& \text { Keterangan : } \\
& \mathrm{Y}=\text { Belanja Daerah }(\mathrm{BD}) \\
& \mathrm{a} \quad=\text { Konstanta } \\
& \mathrm{b} 1 \mathrm{~b} 2=\text { Koefisien Regresi } \\
& \text { DAU }=\text { Jumlah DAU } \\
& \text { PAD }=\text { Jumlah PAD } \\
& \mathrm{e} \quad=\text { error term }
\end{aligned}
$$

\section{HASIL DAN PEMBAHASAN}

Pada bagian ini penulis akan menjelaskan secara deskriptif variabel penelitian. Statistikdeskriptifdari data masingmasing variable dapat dilihat padaTabel 1 dibawah ini. 
Tabel 1.UjiStatistikDeskriptif(Juta Rupiah)

\begin{tabular}{|c|c|c|c|c|}
\hline \multicolumn{5}{|c|}{ Statistics } \\
\hline & & $\mathrm{BD}$ & DAU & PAD \\
\hline \multirow[t]{2}{*}{$\mathrm{N}$} & Valid & 95 & 95 & 95 \\
\hline & Missing & 0 & 0 & 0 \\
\hline \multicolumn{2}{|c|}{ Mean } & 518895.9684 & 327919.2526 & 29290.3789 \\
\hline \multicolumn{2}{|c|}{ Median } & 478137.0000 & 297522.0000 & 22176.0000 \\
\hline \multicolumn{2}{|c|}{ Mode } & $190270.00^{a}$ & $187600.00^{a}$ & $20005.00^{a}$ \\
\hline \multicolumn{2}{|c|}{ Std. Deviation } & 213748.19824 & 112785.67132 & 29194.68847 \\
\hline \multicolumn{2}{|c|}{ Variance } & 45688292251 & 12720607654 & 852329834.7 \\
\hline \multicolumn{2}{|c|}{ Range } & 1209942.00 & 515516.00 & 194092.00 \\
\hline \multicolumn{2}{|c|}{ Minimum } & 190270.00 & 187600.00 & 8873.00 \\
\hline \multicolumn{2}{|c|}{ Maximum } & 1400212.00 & 703116.00 & 202965.00 \\
\hline \multicolumn{2}{|c|}{ Sum } & 49295117.00 & 31152329.00 & 2782586.00 \\
\hline
\end{tabular}

a. Multiple modes exist. The smallest value is shown

Dari hasil pengolahan data terlihat nilai statistik dari masingmasing variabel penelitian, dimana untuk variabel belanja daerah terlihat bahwa nilai terendah adalah sebesar 190.270 dan nilai tertinggi adalah sebesar 1.400.212 dan nilai rata-rata adalah 518.896,97 dengan standar deviasi sebesar 213.748,19. Jadi terlihat bahwa nilai rata-rata belanja daerah lebih besar jika dibandingkan dengan standar deviasi, hal ini menunjukkan belanja daerah adalah valid dan bagus.

Variabel dana alokasi umum mempunyai nilai terendah sebesar 187.600 dan nilai tertinggi adalah sebesar 703.116 dan nilai rata-rata adalah sebesar 327.919,25 dengan standar deviasi sebesar 112.785,67. Maka tergambar bahwa nilai ratarata dana alokasi umum lebih besar jika dibandingkan dengan standar deviasi, hal ini menunjukkan dana alokasi umum adalah valid dan bagus.

Variabel pendapatan asli daerah mempunyai nilai terendah sebesar 8.873 dan nilai tertinggi adalah sebesar 202.965 dan nilai rata-rata adalah sebesar 29.290,38 dengan standar deviasi sebesar 29194,69. Maka tergambar bahwa nilai ratarata pendapatan asli daerah lebih besar jika dibandingkan dengan standar deviasi, hal ini menunjukkan pendapatan asli daerah adalah valid dan bagus.

\section{Uji Asumsi Klasik}

Uji asumsi klasik digunakan untuk mendapatkan penduga koefisien regresi yang mempunyai error terkecil atau model regresi yang dihasilkan adalah mempunyai sifat BLUE (Best Linier Unbiased Estimate) atau mempunyai sifat yang linear, tidak bias dan varian minimum. 


\section{a. Uji Normalitas}

Pengujian terhadap normalitas data ini dilakukan untuk mengetahui apakah data mengikuti pola distribusi normal atau tidak. Model regresi yang baik adalah distribusi data normal atau mendekati normal. Berdasarkan hasil analisis data terhadap pengujian normalitas disajikan pada Tabel 2 di bawah ini:

Tabel 2Uji Normalitas Data

One-Sample Kolmogorov-Smirnov Test

\begin{tabular}{|c|c|c|}
\hline & & $\begin{array}{l}\text { Unstandardiz } \\
\text { ed Residual }\end{array}$ \\
\hline \multicolumn{2}{|l|}{$N$} & 95 \\
\hline \multirow[t]{2}{*}{ Normal Parameters } & Mean & .0000000 \\
\hline & Std. Deviation & 77253.78199 \\
\hline Most Extreme & Absolute & .065 \\
\hline \multirow[t]{2}{*}{ Differences } & Positive & .042 \\
\hline & Negative & -.065 \\
\hline Kolmogorov-Smirnov Z & & .635 \\
\hline Asymp. Sig. (2-tailed) & & .815 \\
\hline
\end{tabular}

a. Test distribution is Nomal.

b. Calculated from data.

Berdasarkan tabel di atas terlihat semua variable residual memiliki nilai signifikansi sebesar 0,815 yaitu lebih besar dari alpha $(0,815>0,05)$. Dengan demikian dapat dikatakan bahwa data hasil penelitian sudah berdistribui normal sehingga analisis regresi dapat dilaksanakan.

\section{b. Uji Multikolinearitas}

Salah satu syarat untuk memakai analisis dengan menggunakan regresi linear berganda terlebih dahulu dilakukan uji multicolinearitas yaitu uji hubungan

Tabel 4.HasilUjiMultikolinearitas sesama variabel bebas. Multikolineritas adalah keadaan dimana variabel-variabel independen dalam persamaan regresi mempunyai korelasi (hubungan) yang erat satu sama lain (Gujarati, 2003). Analisis ini bertujuan untuk melihat korelasi sesama variabel bebas. Apabila terdapat korelasi yang tinggi sesama variabel bebas maka salah satu diantaranya dieleminir atau dikeluarkan dari model regresi berganda.

Hasil uji multikolineritas data hasil penelitian dapat dilihat pada Tabel 3 di bawah ini. 
Coefficie nts ${ }^{a}$

\begin{tabular}{|ll|r|r|}
\hline \multirow{2}{*}{ Model } & \multicolumn{2}{|c|}{ Collinearity Statistics } \\
\cline { 3 - 4 } & & Tolerance & VIF \\
\hline 1 & DAU & .588 & 1.701 \\
& PAD & .588 & 1.701 \\
\hline
\end{tabular}

a. Dependent Variable: $B D$

Berdasarkan hasil analisis data

untuk uji multikolinearitas sebagaimana pada di atas maka diketahui nilai tolerance masingmasing variabel bebas adalah 0,588 dan nilai VIF sebesar 1,701. Hal ini menunjukkan bahwa nilai VIF dari semua variabel bebas adalah lebih besar dari 10. Dengan demikian dapat dikatakan bahwa sesama variabel bebas tidak memiliki hubungan yang kuat satu sama lainnya. Dengan demikian dapat dikatakan bahwa data hasil penelitian ini tidak mengalami kasus multikolineritas, artinya bahwa sesama variabel bebas tidak berkorelasi kuat satu sama lainnya sehingga analisis regresi linear berganda dapat dilakukan karena tidak terjadi multikolinearitas.

\section{c. Uji Heteroskedastisitas}

Uji Heterokedastisitas bertujuan untuk menguji apakah dalam sebuah model regresi terjadi ketidaksamaan varian dari residual suatu persamaan ke pengamatan lain. Jika varians dari residual dari satu pengamatan ke pengamatan lain tetap, maka disebut Homokedastisitas. Sedangkan jika varians berbeda, maka disebut heterokedastisitas. Sedangkan model regresi yang baik adalah jika tidak terjadinya heterokedastisitas. Untuk mendeteksi adanya heterokedastisitas dapat menggunakan uji Gletser. Hasil pengujian heteroskedastisitas dapat dilihat pada tabel 5 di bawah ini:

Tabel 5.HasilUjiHeterokedastisitas

\begin{tabular}{|l|l|c|rr|r|}
\hline o & \multicolumn{1}{|c|}{ Variabel } & ig & lpa & Keterangan \\
\hline & Dana Alokasi Umum &, 194 &, 05 & 0 & Tidak heteroskedastisitas \\
\hline & Pendapatan Asli Daerah &, 208 &, 05 & 0 & Tidak heteroskedastisitas \\
\hline
\end{tabular}

Dari Tabel 5 terlihat bahwa tidak terjadi heteroskedastisitas karena nilai signifikan dari semua variabel bebas lebih besar dari alpha $(0,05)$. Dengan demikian analisis regresi dapat dilakukan 
karena tidak terjadi heteroskedastisitas.

\section{d. Uji Autokorelasi}

Uji autokorelasi bertujuan menguji apakah dalam model regresi linier berganda ada korelasi antara kesalahan pengganggu pada periode $\mathrm{t}$-1 (sebelumnya). Tabel 6.HasilUjiAutokorelasi

\begin{tabular}{|c|c|}
\hline Model & Durbin Watson \\
\hline 1 & 1.767 \\
\hline
\end{tabular}

Dari hasil uji tabel 4.6 terlihat bahwa nilai Durbin Watson sebesar 1.948004. Nilai ini terletak antara -2 dengan +2 sehingga dapat dikatakan bahwa model regresi tidak mengandung autokorelasi.

A.

ngujian Hipotesis

Berikut disajikan hasil pengujian masing-masing
Pengujian autokorelasi ini dengan menggunakan Durbin Watson dengan kriteria pengambilan keputusan jika nilai Durbin Watson antara -2 dan +2 maka tidak terjadi autokorelasi diperoleh nilai Durbin Watson pada tabel 6

Tabel 7.HasilUjiHipotesis

\begin{tabular}{|l|l|c|c|c|c|c|}
\hline No & \multicolumn{1}{|c|}{ Variabel } & Notasi & Koefisien & t hitung & Prob & Ket \\
\hline & Konstanta & $\mathrm{a}$ & $17.746,2$ & & & \\
\hline $\begin{array}{l}\text { Dana Alokasi } \\
\text { Umum }\end{array}$ & $\mathrm{X} 1$ & 1,511 & 16,220 & 0.00 & Signifikan \\
\hline $\begin{array}{l}\text { Pendapatan Asli } \\
\text { Daerah }\end{array}$ & $\mathrm{X} 2$ & 1,409 & 3,917 & 0.00 & Signifikan \\
\hline $\begin{array}{l}\text { R Square }=0,869 \\
\text { F Hitung }=306,416 \\
\text { F Prob. }=0,000\end{array}$
\end{tabular}

Dari tabel di atas dapat dilihat nilai konstanta sebesar 17.746,2 dan nilai koefisien regresi dari dana alokasi umum (DAU) adalah sebesar 1,511. Berdasarkan hasil analisis hipotesis yang diuji dalam penelitian ini disertai pembahasan masing-masing hipotesis penelitian.Pengujian hipotesis pada penelitian adalah untuk menguji ada tidaknya pengaruh dana alokasi umum (DAU)dan pendapatan asli daerah (PAD)terhadap belanja daerah (BD). Hasil pengujiannya dapat dilihat pada tabel di bawah ini: 
1. Nilai koefisien konstanta sebesar 17.746,2 menunjukkan bahwa besarnya belanja daerah tanpa dipengaruh oleh DAU dan PAD adalah sebesar 17,746 milyar

2. Nilai koefisien regresi dana alokasi umum sebesar 1,515, nilai t hitung 16,220 serta nilai signifikansi sebesar $0,00<0.05$. Hal ini berarti hipotesis pertama yang menyatakan Dana Alokasi Umum (DAU) berpengaruh positif signifikan terhadap belanja daerah dapat diterima. Koefisien variabel dana alokasi umum bernilai positif, ini menyatakan bahwa jika terjadi peningkatan jumlah dana alokasi umum akan terjadi juga peningkatan pada jumlah belanja daerah yang akan dikeluarkan oleh pemerintah Kabupaten/Kota di Provinsi Sumatera Barat.

3. Nilai koefisien regresi pendapatan asli daerah sebesar 1,409, nilai t hitung 3,917 serta nilai signifikansi sebesar $0,00<$ 0.05. Hal ini berarti hipotesis kedua yang menyatakan pendapatan asli daerah berpengaruh positif signifikan terhadap belanja daerah dapat diterima. Koefisien variabel pendapatan asli daerah bernilai positif ini menyatakan bahwa jika terjadi peningkatan pendapatan asli daerah akan terjadi juga peningkatan pada jumlah belanja daerah yang akan dikeluarkan oleh pemerintah
Kabupaten/Kota di Provinsi Sumatera Barat.

\section{B. Pembahasan Hasil Penelitian \\ 1. Pengaruh DAU Terhadap Belanja Daerah}

Hasil pengujian hipotesis pertama diketahui bahwa Dana Alokasi Umum (DAU) berpengaruh positif signifikan terhadap Belanja Daerah (BD)Kabupaten/Kota di Provinsi Sumatera Barat. Jika terjadi peningkatan jumlah dana alokasi umum akan terjadi juga peningkatan pada jumlah belanja daerah yang akan dikeluarkan oleh pemerintah Kabupaten/Kota di Provinsi Sumatera Barat.

\begin{tabular}{lll}
\multicolumn{2}{c}{ Dalam menjalankan } & tugasnya \\
sebagai daerah & otonom, \\
Kabupaten/Kota di & Provinsi
\end{tabular}
Sumatera Barat sangat bergantung pada dana perimbangan dari pemerintah pusat berupa bagi hasil pajak, bagi hasil Sumber DayaAlam, Dana AlokasiUmum (DAU) dan Dana AlokasiKhusus (DAK).Dana Alokasi Umum (DAU) merupakan penyanggah utama pembiayaan APBD sebagian besar terserap untuk belanja pegawai.

Dana Alokasi Umum (DAU) merupakan dana yang berasal dari APBN, yang dialokasikan dengan tujuan pemerataan kemampuan keuangan antar daerah untuk membiayai kebutuhan pembelanjaan dalam rangka pelaksanaan desentralisasi. Ketergantungan daerah pada pemerintah pusat tidak 
berarti bahwa daerah kurang berusaha untuk meningkatkan Pendapatan Asli Daerah (PAD), atau karena potensi pendapatan yang ada di daerah sangat terbatas.

Temuan penelitian ini didukung oleh pendapat Halim (2004) yang menyatakan bahwa Dana Alokasi Umum (DAU) merupakan dana transfer dari pemerintah pusat yang berasal dari APBN, yang dialokasikan dengan tujuan pemerataan kemampuan keuangan antar daerah untuk membiayai kebutuhan pembelanjaan dalam rangka pelaksanaan desentralisasi. DAU dialokasikan untuk daerah provinsi dan daerah Kabupaten/Kota

\section{Pengaruh PAD Terhadap Belanja Daerah}

Hasil pengujian hipotesis kedua diketahui bahwa Pendapatan Asli Daerah (DAU) berpengaruh positif signifikan terhadap Belanja Daerah (BD)Kabupaten/Kota di Provinsi Sumatera Barat. Jika terjadi peningkatan jumlah dana alokasi umum akan terjadi juga peningkatan pada jumlah belanja daerah yang akan dikeluarkan oleh pemerintah Kabupaten/Kota di Provinsi Sumatera Barat

Jika ada peningkatan jumlah Pendapatan Asli Daerah (PAD) maka akan terjadi peningkatan pula pada jumlah belanja daerah yang akan dikeluarkan oleh pemerintah
Kabupaten/Kota di Provinsi

Sumatera Barat.

Berdasarkan hasil penelitian ini berarti pemerintah daerah Kabupaten/Kota di Provinsi Sumatera Barat telah mampu menggali potensi sumber-sumber keuangannya berupa pendapatan asli daerah dan menggunakannya untuk membiayai belanja daerahnya. Pemerintah daerah selain bergantung pada pemerintah pusat berupa transfer dana perimbangan dari pusat dalam membiayai belanja daerahnya, mereka juga bisa mendanai belanja daerahnya dengan memanfaatkan Pendapatan Asli Daerah (PAD) yang bersumber dari Pajak Daerah, Retribusi Daerah, Hasil perusahaan milik daerah dan hasil pengelolaan kekayaan milik daerah yang dipisahkan dan Lain-lain PAD yang sah.

Pendapatan asli daerah dapat berasal dari Pajak Daerah, merupakan pendapatan daerah yang berasal dari pajak. Retribusi Daerah, merupakan pendapatan daerah yang berasal dari retribusi daerah. Hasil perusahaan milik daerah dan hasil pengelolaan kekayaan milik daerah yang dipisahkan, merupakan penerimaan daerah yang berasal dari hasil perusahaan milik daerah dan pengelolaan kekayaan daerah yang dipisahkan.

Hasil penelitian ini didukung oleh pendapat Halim (2004) menegaskan bahwa Belanja daerah akan ditentukan oleh Pendapatan 
Asli Daerah (PAD). Semakin besar Pendapatan Asli Daerah (PAD) tentunya memberikan dampak positif terhadap peningkatan Belanja Daerah (BD). Apabila pemerintah daerah dapat menutupi segala kebutuhan belanja daerah dengan pendapatan sendiri tentunya menandakan tingginya tingkat kemandirian daerah dalam menjalani otonomi daerah.

\section{KESIMPULAN DAN SARAN}

Berdasarkan analisis data dan pembahasan yang dikemukakan pada bab sebelumnya maka dapat diambil kesimpulan seperti yang diuraikan berikut ini:

1. Dana Alokasi Umum (DAU) pada Kabupaten/Kota di Provinsi Sumatera Barat berpengaruh signifikan terhadap belanja daerah. Peningkatan jumlah Dana alokasi Umum (DAU) akan mengakibatkan peningkatan pada jumlah Belanja Daerah yang akan dikeluarkan oleh pemerintah Kabupaten/Kota di Provinsi Sumatera Barat.

2. Pendapatan Asli Daerah (PAD) pada Kabupaten/Kota di Provinsi Sumatera Barat berpengaruh signifikan terhadap belanja daerah. Peningkatan jumlah Pendapatan Asli Daerah (PAD) akan mengakibatkan peningkatan pada jumlah Belanja Daerah yang akan dikeluarkan oleh pemerintah Kabupaten/Kota di Provinsi Sumatera Barat

\section{Implikasi Penelitian}

a. Implikasi Teoritis

Hasil penelitian ini dapat menjadi tambahan referensi bagi pembaca untuk memahami lebih mendalam tentang pengaruh DAU dan PAD terhadap belanja daerah.

\section{b. Implikasi Praktis}

Dari hasil penelitian ini memberikan bukti empiris bahwa dalam mengamati belanja daerah pada Kabupaten/Kota di Provinsi Sumatera Barat maka dapat dirumuskan implikasi kebijakan sebagai berkut :

1. Bagi Pemerintah daerah diharapkan untuk mempedomani hasil penelitian ini dalam rangka pelaksanaan otonomi daerah dan membiayai belanja daerah.

2. Dana Alokasi Umum (DAU) dan Pendapatan Asli Daerah (PAD) dapat dimanfaatkan secara efektif dan efisien dalam membiayai belanja daerah.

3. Dalam rangka otonomi daerah pemerintah daerah Kabupaten/Kota di Provinsi Sumatera Barat masih tergantung pada transfer dari pusat.

4. Bagi akademis hasil penelitian ini bisa dijadikan referensi tentang sumber keuangan daerah dan alokasi pembiayaan belanja.

c.

\section{san Penelitian dan Saran}

Adapun keterbatasan penelitian dan saran untuk penelitian berikutnya adalah : 
1. Penelitian ini dilakukan pada Kabupaten/Kota di Provinsi Sumatera Barat disarankan untuk penelitian berikutnya agar menggunakan sampel yang lebih banyak dengan periode pengamatan yang panjang agar hasil penelitian dapat digeneralisasikan.

2. Model análisis yang digunakan pada penelitian adalah regresi linear sederhana dan regresi linear berganda serta uji beda, disarankan disarankan untuk menggunakan model yang lain agar dapat mengeneralisir hasil penelitian lebih komprehensif seperti halnya menggunakan analisis faktor, structure equation model (SEM).

3. Belum dapat tergambar dengan baiknya proksi prilaku pengalokasian sumber daya oleh pengelola keuangan daerah dan politisi dikarenakan penggunaan data sekunder yang diperoleh dari laporan realisasi AF'BD. Dibutuhkan pendekatan lain yang lebih feasible, misalnya dengan melakukan field research atau eksperimen (dengan subjek eksekutif dan legislative daerah).

4. Variabel yang diteliti hanya menggunakan dua variabel yang mempengaruhi Belanja Daerah yaitu Dana Alokasi Umum (DAU) dan Pendapatan Asli Daerah (PAD), sehingga bagi peneliti selanjutnya agar memasukkan variabel-variabel lain yang dapat mempengaruhi Belanja Daerah (misalnya Dana Alokasi Khusus, dana hibah, dll).

\section{UCAPAN TERIMAKASIH}

Terbitnya tulisan ini tidak terlepas dari bantuan berbagai pihak, untuk itu penulis ucapkan terima kasih yang sebesar-basarnya kepada Pihak STKIP PGRI Sumatera Barat khususnya pengelola jurnal Pelangi yang telah memberikan kesempatan kepada penulis untuk menulis dijurnal Pelangi.Selanjutnya penulis juga berterima kasih kepada para penyumbang sumber insirasi yang telah memerikan inspirasi bagi penulis untuk mengutip atau menggunakan tulisannya sebagai bahan referensi.

\section{DAFTARPUSTAKA}

Abdullah, Sukriy dan Halim, Abdul.2003.Pengaruh DAU dan PAD terhadap Belanja Daerah Studi Kasus Kabupaten/Kota di Jawa-Bali.Simposium Nasional Akuntansi VI, Yogyakarta.

Adi, P.H. 2005. Implementasi Activity Based Costing Terhadap Kinerja Perusahaan, Jurnal. Ekonomi dan Bisnis, XI (2), 101-118, Maret 2005

Gujarati, Damodar. 2003. Ekonometrika Dasar : Edisi Keenam. Jakarta: Erlangga

Kusuma, Dewi dan Arief Rahman. 2007. Flypaper Effct pada Dana Alokasi Umum (DAU) dan Pendapatan Asli Daerah (PAD) 
terhadap Belanja Daerah pada Kabupaten/Kota Di Indonesia, JAAI Volume 11 No.1, Juni 2007.

Maimunah, Mutiara. 2006 : Flypaper Effect Pada Dana Alokasi Umum dan Pendapatan Asli Daerah Terhadap Belanja Daerah pada Kabupaten/Kota di Pulau Sumatera, Simposium Nasional Akuntansi 9 Padang, K-ASPP 04.

Maimunah, Mutiara dan Akbar Rusdi 2008 : Flypaper Effect Pada Dana Alokasi Umum dan Pendapatan Asli Daerah Terhadap Belanja Daerah pada Kabupaten/Kota di Pulau Sumatera, Jurnal Riset Akuntansi Indonesia. Vol.11, No.1, Januari 2008.

Nachrowi D., dan Hardius Usman, 2006.Pendekatan Populer dan dan.Praktis Ekonometrika Untuk Analisis Ekonomi dan Keuangan. Yogyakarta: Pustaka Pelajar.

PermendagriNomor 13 Tahun 2006. Tentang Pedoman Pengelolaan Keuangan Daerah. Jakarta Ditjen Perbendaharaan Departemen Keuangan RI.

Tentang Perubahan Atas Peraturan Menteri Dalam Negeri Nomor 13 Tahun 2006 Tentang Pedoman Pengelolaan Keuangan Daerah. Direktorat Jenderal Bina Administrasi Keuangan Daerah.
Peraturan Pemerintah Nomor 58 Tahun 2005. Tentang Pengelolaan Keuangan Daerah. Jakarta. Ditjen Perbendaharaan Departemen Keuangan RI.

Prakosa, Kesit, Bambang, 2004. Analisis Pengaruh Dana Alokasi Umum (DAU) dan Pendapatan Asli Daerah (PAD) Terhadap Belanja Daerah (studi empiric di wilayah Propinsi Jawa Tengah dan DIY), JAAI Vol.8 No.2, 2004.

Republik Indonesia 2004.UndangUndang Republik Indonesia No. 32/2004 tentang Pemerintahan Daerah. Republik Indonesia No. 33/2004 tentang Perimbangan Keuangan Pemerintahan Pusat dan Pemerintah Daerah.

Sugiyono. 2007. Metode Penelitian Administrasi. Bandung, CV Alfabeta.

Thahjanulin, Domai. 2008. Reinventing Keuangan Daerah studi tentang pengelolaan Keuangan Daerah. Jurnal Administrasi Negara.Vol.11 No.02 Maret 2002.http://www.google.com/rei nventing keuangan daerah accesed on march 20.2008.

Undang-undang Nomor 32 tahun 2004 tentang Pemerintah Daerah.

----------, Nomor 33 tahun 2004 tentang Perimbangan Keuangan Antara Pemerintah Pusat dan Pemerintah Daerah. 
Nomor 28 tahun 2009

tentang Pajak dan Retribusi

Daerah.

Yani, Ahmad. 2008. Hubungan Keuangan antara pemerintah pusat dan daerah Indonesia, RajaGrapindo persada.

Zampelli, Ernest M.1986. resource fungibility,the flypaper effect, and the Expenditure impact of grants-in-aid. The Review of economics and Statistic 67;3340. 